\title{
Effect of Eugenol on Growth and Listeriolysin O Production by Listeria monocytogenes
}

\author{
Cristina Tostes Filgueiras ${ }^{1}$ and Maria Cristina Dantas Vanetti $^{2 *}$ \\ ${ }^{1}$ Universidade para o Desenvolvimento do Estado e da Região do Pantanal; Rua Alexandre Herculano, 1400; \\ Parque dos Poderes; 79037-280; Campo Grande - MS - Brasil. ${ }^{2}$ Departamento de Microbiologia; Universidade \\ Federal de Viçosa; mvanetti@ufv.br; 36570-000; Viçosa - MG - Brasil
}

\begin{abstract}
The inhibitory effect of eugenol, a naturally occurring compound mainly present in the essential oil fraction of cloves, was studied on the growth and listeriolysin $O(L L O)$ production by Listeria monocytogenes. Potassium efflux from cells promoted by eugenol was also determined after $24 \mathrm{~h}$ incubation in phosphate buffered saline. Eugenol promoted a delay on the growth of $\underline{L}$. monocytogenes at concentrations of 100, 300 and $500 \mu \mathrm{g} \mathrm{mL}^{-1}$ and above 800 $\mu \mathrm{g} \mathrm{mL^{-1 }}$ the effect was bactericidal. Production of LLO by $\underline{L}$. monocytogenes in the presence of eugenol was reduced 80-100\%. An accumulation of external $K^{+}$was observed above $300 \mu \mathrm{g} \mathrm{mL^{-1 }}$ of eugenol which indicated that the cell membrane was affected. The results showed the effectiveness of eugenol in controlling growth and LLO production of L. monocytogenes cells.
\end{abstract}

Key words: Eugenol, Listeria monocytogenes, antilisteric, LLO

\section{INTRODUCTION}

Listeria monocytogenes is a Gram-positive, facultative anaerobic rod and psychrotrophic bacterium, which is associated with foodborne disease. This pathogen produces several characterized virulence factors. Listeriolysin $\mathrm{O}$ (LLO) is considered the major of them and is produced by all pathogenic strains of $L$. monocytogenes (Dimmig et al., 1994; Kim et al., 1994; Giammarini et al., 2004). The environmental conditions in which L. monocytogenes can grow affect its virulence and LLO production (McKellar, 1993; Dimmig et al., 1994; Kim et al., 1994).

The ubiquitous distribution of this pathogen in nature, its ability to proliferate at refrigeration temperature and its tolerance to certain preservatives have resulted in an extensive effort to develop processes to control its growth in foods. Mild preservation technologies are becoming more important in modern food industries, and essential oils should be an alternative to combine mild process to obtain safe products (Ultee et al., 1999). The antilisterial properties of these components have been described. Essential oils of cinnamon, clove, oregano, pimento and thyme showed antilisteric effectiveness in tryptone soy broth (Aureli et al., 1992). In minced pork meat added of thyme oil, the population of L. monocytogenes was reduced approximately 100 fold over the first week of storage (Aureli et al., 1992). Rosemary oil, at $10 \mu \mathrm{LL}^{-1}$ in brain heart infusion was listeriostatic after $24 \mathrm{~h}$ of incubation (Pandit and Shelef, 1994). Clove and its essential oil had been

\footnotetext{
* Author for correspondence
} 
considered by Smith-Palmer et al. (1998) as the most applicable spices to control of $L$. monocytogenes in foods. Clove oil at $1 \%$ reduced the number of L. monocytogenes of $10^{6}$ to $<1$ $\log _{10}$ CFU (colony forming unit) $\mathrm{g}^{-1}$ in low and full fat cheese (Smith-Palmer et al., 2001). The antilisteric activity of clove oil was confirmed in cheese and meat when added at concentration of $0.5 \%$ and $1 \%$ (Menon and Garg, 2001). Other pathogens and foodborne microorganisms also showed sensitivity to this spice or its essential oil (Stecchini et al., 1993; Bara and Vanetti, 1995; Smith-Palmer et al., 1998; Suhr and Nielsen, 2003).

The mechanism of action of the antimicrobial activity of botanical biopreservatives is not fully understood (Draughon, 2004). The antimicrobial effect of clove is attributed to eugenol, which is the major active constituent of its essential oil (Pruthi, 1980). Although the exact inhibitory action of eugenol on microorganisms has not yet been established, it is widely believed that its action would be similar to the other phenolic compounds exhibiting antimicrobial activity. The microbial inhibition of eugenol might be related to the membrane disruption or, according to Wendakoon and Sakaguchi (1993), by inactivation of enzymes and genetic materials. A better knowledge of the mode of action of eugenol on microbial cells is important regarding its application in food systems.

This study was conducted to determine the activity of eugenol on liquid media on L. monocytogenes cells and its effect on LLO production.

\section{MATERIALS AND METHODS}

\section{Strain and culture conditions}

L. monocytogenes strain Scott A was obtained from the Department of Food Science and Nutrition at São Paulo University (SP, Brazil). Stock cultures were maintained on tryptone soy agar (TSA Oxoid, Basingstoke, HA) slants at $5{ }^{\circ} \mathrm{C}$ and transferred monthly. Cells were activated in tryptone soy broth - TSB at $37{ }^{\circ} \mathrm{C} \pm 2{ }^{\circ} \mathrm{C}$ for $18 \mathrm{~h}$. A suspension of $10^{8} \mathrm{CFUmL}^{-1}$ in $0.85 \%$ saline solution was prepared and used as inoculum.

\section{Determination of effect of eugenol against $L$. monocytogenes}

Eugenol (2-methoxy-4-[2proenyl]phenol) was obtained from Sigma Chemical Co. (St Louis, $\mathrm{MO})$. A stock solution was prepared by dissolving $100 \mathrm{mg}$ of eugenol in $10 \mathrm{~mL}$ of $95 \%$ ethanol. Aliquots were added to sterilized and cooled proteose peptone broth - PPG (Geoffroy et al., 1989) to give the final concentrations of 100,300 , 500, 800 and $1000 \mu \mathrm{g} \mathrm{mL}^{-1}$. In order to detect the absence of antibacterial activity of ethanol, the experiments were performed with a control, with the solvent added to the medium.

The bacterial suspension was diluted to $10^{7} \mathrm{CFU}$ $\mathrm{mL}^{-1}$ in saline solution and $100 \mu \mathrm{L}$ were used to inoculate $5 \mathrm{~mL}$ of broth. Cultures were incubated at $37{ }^{\circ} \mathrm{C}$ and growth was determined at $600 \mathrm{~nm}$ $\left(\mathrm{OD}_{600}\right)$ using a Spectronic 20 (Milton Roy, Rochester, NY) spectrophotometer. The viability of the cells treated with eugenol was evaluated by colony counts on the surface of TSA plates.

At $24 \mathrm{~h}$ incubation, $1.5 \mathrm{~mL}$ of cultures were centrifuged at $10,000 \mathrm{~g}$ for $5 \mathrm{~min}$ to remove cells. The supernatants were filter sterilized and used as the source of LLO.

\section{LLO assay}

LLO activity was determined using sheep red blood cells as described by McKellar (1992). The percentage of haemolysis was determined by comparison with a control without eugenol.

\section{Determination of extracellular $\mathrm{K}^{+}$}

The efflux of $\mathrm{K}^{+}$ions from $L$. monocytogenes treated with eugenol was determined by estimating potassium concentration in the external cell-buffer system. Overnight cells grown on PPG were harvested by centrifugation $(16,000 \mathrm{~g}, 10 \mathrm{~min})$ and washed in $0.85 \%$ saline solution. The cell mass obtained was resuspended in $5 \mathrm{~mL}$ of phosphate buffered saline (PBS) (McKellar, 1992), pH 7.4 containing $100,300,500,800$ and $1000 \mu \mathrm{g} \mathrm{mL}^{-1}$ of eugenol. After $24 \mathrm{~h}$ incubation at $37{ }^{\circ} \mathrm{C}$ cells were removed by filtration and $\mathrm{K}^{+}$ions determined by atomic absorption spectrophotometer (Perkin Elmer, Brookfield, CT). A standard calibration curve was made with $\mathrm{KCl}$ solutions.

All the experiments were performed in two sets, in duplicate and the data expressed as the average of the results. 


\section{RESULTS}

Concentrations up to $300 \mu \mathrm{g} \mathrm{mL}^{-1}$ eugenol extended the lag phase but did not cause changes in the final $\mathrm{OD}_{600}$ of cultures of $L$. monocytogenes (Fig. 1). No growth was detected in PPG broth with 800 or $1000 \mu \mathrm{g} \mathrm{mL} \mathrm{m}^{-1}$ eugenol over $48 \mathrm{~h}$ incubation and some decreased in $\mathrm{OD}_{600}$ indicating cell lysis was found at highest eugenol concentration (Fig. 1). The influence of ethanol used as eugenol diluent on the growth of $L$. monocytogenes was examined and it was found that the addition of up $1000 \mu \mathrm{g} \mathrm{mL}^{-1}$ ethanol to the PPG broth did not cause any changes in the growth curve of L. monocytogenes (data not shown). In order to verify if eugenol was bacteriostatic or bactericidal, the viable cell number was determined.

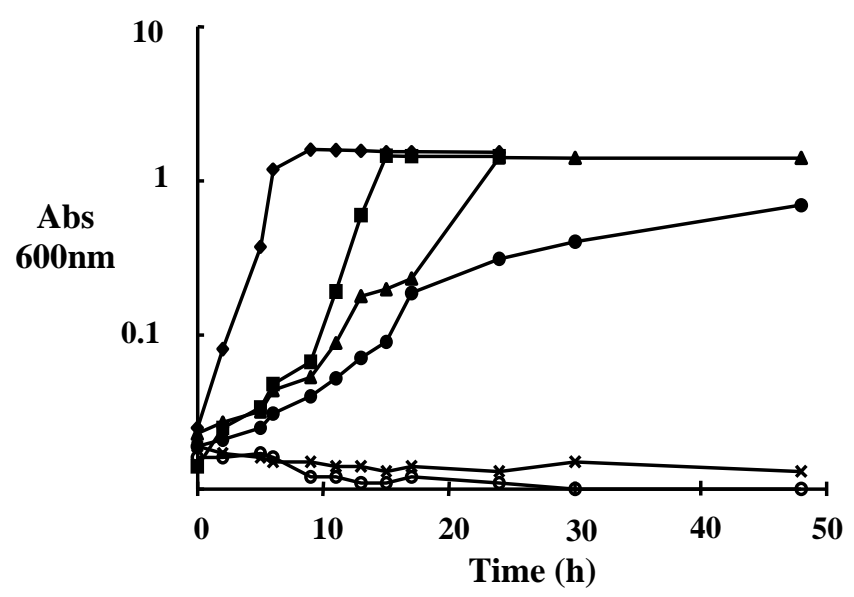

Figure 1 - Growth of Listeria monocytogenes Scott A at $37{ }^{\circ} \mathrm{C}$ in proteose pepton broth containing eugenol. (•) Control; (•) $100 \mu \mathrm{g} \mathrm{mL}^{-1}$; (A) $300 \mu \mathrm{gmL}^{-1}(\bullet) 500 \mu \mathrm{g}$ $\mathrm{mL}^{-1}$; (x) $800 \mu \mathrm{g} \mathrm{mL}^{-1}$; (०) $1000 \mu \mathrm{g} \mathrm{mL}^{-1}$.

The bactericidal effect of eugenol was evidenced at $800 \mu \mathrm{g} \mathrm{mL}^{-1}$ when a reduction of viable counts of L. monocytogenes was about $6 \log$ cycles after $10 \mathrm{~h}$ incubation (data not shown). At the same time, no viable cells were detected in the presence of $1000 \mu \mathrm{g} \mathrm{mL}^{-1}$. When cells were maintained for $24 \mathrm{~h}$ at $37{ }^{\circ} \mathrm{C}$ in PBS buffer containing $100 \mu \mathrm{g} \mathrm{mL}^{-1}$ eugenol, no $\mathrm{K}^{+}$was lost. However, in the presence of over $300 \mu \mathrm{g} \mathrm{mL}^{-1}$ eugenol, an accumulation of external $\mathrm{K}^{+}$was observed (Fig. 2). Eugenol increased the $\mathrm{K}^{+}$ion permeability of $L$. monocytogenes cells in a concentration-dependent way and the addition of a bactericidal concentration of eugenol (800 and $1000 \mu \mathrm{g} \mathrm{mL}^{-1}$ ) greatly increased the released of $\mathrm{K}^{+}$in PBS buffer.

The influence of eugenol on LLO activity was also examined and it was observed that the production of LLO was remarkably reduced after $24 \mathrm{~h}$ incubation in the presence of eugenol and complete inhibition was found with $500 \mu \mathrm{g}$ $\mathrm{mL}^{-1}$ (Fig. 2).

\section{DISCUSSION}

Previous studies demonstrated that clove has listericidal effect and our results confirmed that eugenol, a major constituent of essential oil of clove, could respond to this effect. The bactericidal activity of clove against foodborne

pathogens, like L.monocytogenes was reported in TSB by Ting and Deibel (1992) and in saline solution by Aureli et al. (1992). Stecchini et al. (1993) sugested a marked reduction in the number of Aeromonas hydrophila in meat samples treated with clove oil. In combination with $\mathrm{NaCl}$, clove showed a bactericidal effect upon Enterobacter aerogenes in mackerel 
muscle broth (Wendakoon and Sakaguchi, 1993). Clove extract at $2000 \mu \mathrm{g} \mathrm{mL} \mathrm{m}^{-1}$ showed bactericidal activity towards Yersinia enterocolitica in TSB (Bara and Vanetti, 1995). Eugenol was effective at reducing the growth of L. monocytogenes on cooked beef stored at 5 or $15{ }^{\circ} \mathrm{C}$ (Hao et al., 1998). Results presented by Smith-Palmer et al. (1998) established that the essential oil of clove was among the most applicable oil for the control of $L$. monocytogenes as it retained their low bacteriostatic and bactericidal concentrations even at $4{ }^{\circ} \mathrm{C}$. Bactericidal concentrations of clove essential oil against L. monocytogenes was 400 $\mu \mathrm{g} \mathrm{mL}^{-1}$ at $4{ }^{\circ} \mathrm{C}$ and $500 \mu \mathrm{g} \mathrm{mL}^{-1}$ at $35^{\circ} \mathrm{C}$ in TSB broth. In full-fat cheese, clove oil was the only oil, among four oils tested, which reduced $L$.

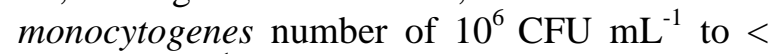
1.0 CFU mL $^{-1}$ (Smith-Palmer et al., 2001).

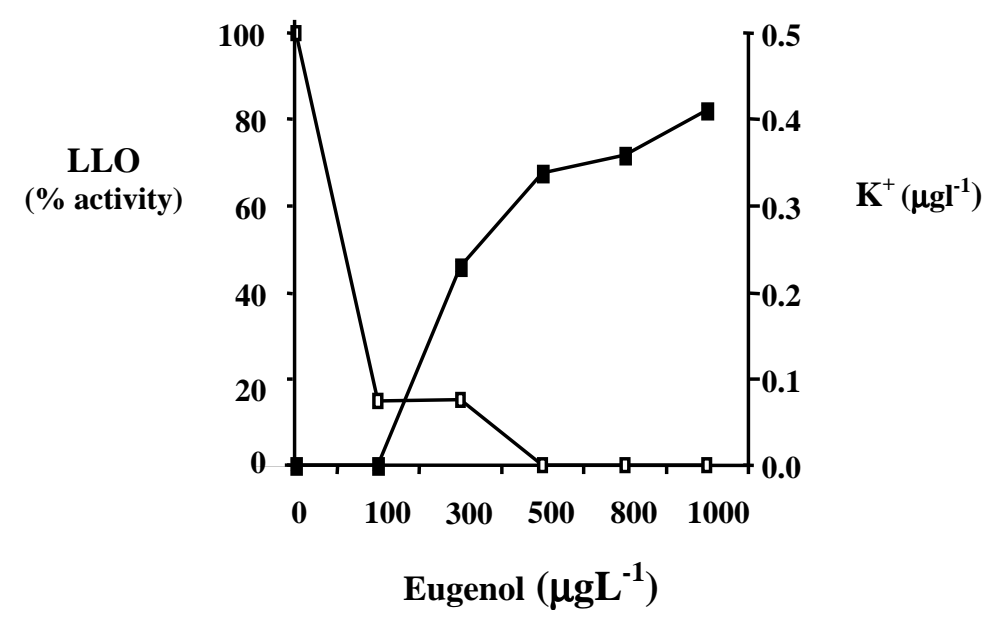

Figure 2 - Effect of eugenol on LLO activity during growth of L. monocytogenes in TSB ( $\square$ ) and on potassium ions efflux in PBS buffer ( $\mathbf{\square})$.

Potassium efflux could be used as an indicator of the membrane damage caused by chemical and physical agents. It has been suggested that the cytoplasmic membrane is also a target for eugenol action and results evidencing the $\mathrm{K}^{+}$efflux corroborated this hypothesis. This result was in agreement with Degré and Sylvestre (1983) who considered that the probable antimicrobial activity of eugenol was on cellular lipids resulting in the loss of intracellular contents. Eugenol was more effective in inhibiting LLO secretion than cellular growth. Other inhibitory agents like sorbate and $\mathrm{NaCl}$ were also more effective to inhibit LLO secretion while having little effect on growth (McKellar, 1993).

Results from the present study indicated that $L$. monocytogenes growth and LLO production were sensitive to eugenol. Although it did not provide support for establishing a link between eugenol and virulence, it contributed to the evaluation of the potential of eugenol in controlling $L$. monocytogenes in foods.

\section{ACKNOWLEDGEMENTS}

The authors would like to thank the Conselho Nacional de Desenvolvimento Científico e Tecnológico-CNPq for the financial support and Coordenação de Aperfeiçoamento de Pessoal Docente-CAPES.

\section{RESUMO}

O efeito inibitório do eugenol, o principal constituinte do óleo essencial de cravo, foi avaliado sobre o crescimento e produção de listeriolisina O (LLO) por Listeria monocytogenes. O efluxo de íons potássio das células também foi 
determinado após $24 \mathrm{~h}$ de incubação em solução tampão, contendo eugenol. Concentrações de 100, 300 e $500 \mu \mathrm{g} \mathrm{mL}^{-1}$ de eugenol promoveram a inibição do crescimento de L. monocytogenes e, em concentrações acima de $800 \mu \mathrm{g} \mathrm{mL} \mathrm{mL}^{-1}$, constatou-se um efeito bactericida. $\mathrm{O}$ crescimento de L. monocytogenes na presença de eugenol resultou na inibição de 80 a $100 \%$ da produção de LLO. O efluxo de $\mathrm{K}^{+}$promovido pelo eugenol indicou que a membrana celular foi afetada. Estes resultados indicam a efetividade do eugenol para o controle do crescimento e da produção de LLO por L. monocytogenes.

\section{REFERENCES}

Aureli, P.; Costentini, A. and Zolea, S. (1992), Antimicrobial activity of some plant essential oils against Listeria monocytogenes. J. Food Protect., 55, 344-348.

Bara, M. T. F. and Vanetti, M. C. D. (1995), Antimicrobial effect of spices on the growth of Yersinia enterocolitica. J. Herbs Spices Med. Plants, 3, 51-58.

Degré, R. and Sylvestre, M. (1983), Effect of butylated hydroxyanisole on the cytoplasmic membrane of Staphylococcus aureus Wood 46. J. Food Protect., 46, 206-209.

Dimmig, L. K.; Myers, E. R. and Martin, S. E. (1994), Catalase, superoxide dismutase and listeriolysin $\mathrm{O}$ production by Listeria monocytogenes in broth containing acetic and hydrochloric acids. J. Food Protect., 57, 626-628.

Draughon, F. A. (2004), Use of botanicals as biopreservatives in foods. Food Technol., 58, 20-28.

Geoffroy, C.; Gaillard, J. L.; Alouf, J. E. and Berche, P. (1989), Production of thiol-dependent haemolysins by Listeria monocytogenes and related species. J. Gen. Microbiol., 135, 481-487.

Giammarini, C.; Andreoni, F.; Amagliam, G.; Casierre, A.; Baroca, S. and Magnani, M. (2004), Purification and characterization of a recombinant listeriolysin $\mathrm{O}$ expressed in Escherichia coli and possible diagnostic application. J. Biotechnol., 109, 13-20.

Hao, Y. Y.; Brackett, R. E. and Doyle, M. P. (1998), Inhibition of Listeria monocytogenes and Aeromonas hydrophila by plat extracts in refrigerated cooked beef. J. Food Protect., 61, 307-312.

Kim, K.; Murano, E. A. and Olson, D. G. (1994), Effect of heat shock on production of listeriolysin $\mathrm{O}$ by Listeria monocytogenes. J. Food Safety, 14, 273-279.

Mckellar, R. C. (1992), Effect of reduced $\mathrm{pH}$ on secretion, stability and activity of Listeria monocytogenes listeriolysin O. J. Food Safety, 12, 283-293.
Mckellar, R. C. (1993), Effect of preservatives and growth factors on secretion of listeriolysin $\mathrm{O}$ by Listeria monocytogenes. J. Food Protect., 56, 380-384.

Menon, K. V. and Garg, S. R. (2001), Inhibitory effect of clove oil on Listeria monocytogenes in meat and cheese. Food. Microbiol., 18, 647-650.

Pandit, V. A. and Shelef, L. A. (1994), Sensitivity of Listeria monocytogenes to rosemary (Rosmarinus officinalis L.). Food Microbiol., 11, 57-63.

Pruthi, J. S. (1980), Spices and condiments: Chemistry, Microbiology, Technology. New York: Academic Press.

Smith-Palmer, A.; Stewart, J. and Fyfe, L. (1998), Antimicrobial properties of plant essential oils and essences against five important food-borne pathogens. Lett. Appl. Microbiol., 26, 118-122.

Smith-Palmer, A.; Stewart, J. and Fyfe, L. (2001), The potential application of plant essential oils as natural food preservation in soft cheese. Food. Microbiol., 18, 463-470.

Stecchini, M. L.; Sarais, I. and Giavedoni, P. (1993), Effect of essential oils on Aeromonas hydrophila in a culture medium and in cooked pork. J. Food Protect., 56, 406-409.

Suhr, K. and Nielsen, P. V. (2003), Antifungal activity of essential oils evaluated by two different application techniques against rye bread spoilage fungi. J. Appl.Microbiol., 94, 665-674.

Ting, W. T. E. and Deibel, K. E. (1992), Sensitivity of Listeria monocytogenes to spices at two temperatures. J. Food Safety, 12, 129-137.

Ultee, A.; Kets, E. P. and Smid, E. J. (1999), Mechanisms of action of carvacrol on the food-borne pathogen Bacillus cereus. Appl. Environ. Microbiol., 65, 4606-4610.

Wendakdoon, C. N. and Sakaguchi, M. (1993), Combined effect of sodium chloride and clove on growth and biogenic amine formation of Enterobacter aerogenes in mackerel muscle extract. J. Food Protect, 56, 410-413.
Received: May 15, 2004; Revised: April 18, 2005; Accepted: January 25, 2006. 